\title{
PENERAPAN STRATEGI GROUP INVESTIGATION UNTUK MENINGKATKANHASIL BELAJAR BIOLOGI MATERI EKOSISTEM BAGI SISWA KELAS XSMA MUHAMMADIYAH AIMAS
}

\section{ANANG TRIYOSO}

SMAMuhammadiyah Aimas

Email : atriyoso@yahoo.com

\begin{abstract}
ABSTRAK
Penelitian ini bertujuan untuk mengetahui peningkatan hasil belajar biologi materi Ekosistem bagi siswa kelas $\mathrm{X}$ SMA Muhammadiyah Aimas.Jenis penelitian ini adalah penelitian tindakan kelas (Classroom Action Research) yang dilakukan dalam dua siklus, masing-masing siklus terdiri dari empat komponen yaitu perencanaan, tindakan, pengamatan, dan refleksi. Instrumen yang digunakan dalam penelitian ini adalah lembar observasi partisipasi aktif siswa, lembar observasi presentasi dan laporan akhir dan soal tes hasil belajar kognitif. Hasil penelitian menunjukkan bahwa persentase partisipasi aktif siswa mengalami peningkatan antara siklus $1(50 \%)$ dan siklus $2(80 \%)$. Peningkatan juga terlihat pada rerata hasil belajar biologi siswa juga mengalami peningkatan antara siklus $1(69,60)$ dan siklus 2 (72). Persentase ketuntasan hasil belajar biologi siswa juga mengalami peningkatan antara siklus $1(70 \%)$ dan siklus 2 (100\%). Berdasarkan hasil penelitian maka disimpulkan bahwa Penerapan strategi Group Investigation dapat meningkatkan hasil belajar siswa kelas X SMA Muhammadiyah Aimas dalam pembelajaran Biologi.
\end{abstract}

Kata kunci : Group Investigation, Hasil Belajar Biologi, SMA Muhammadiyah Aimas

\section{ABSTRACT}

This report aims to review the study results ecosystem biology material for a student XSMAMuhammadiyah Aimas. The research is class actiondone in two cycle, cycle consisting of four components including planning, action, observation, and reflection. An instrument used in research is sheets observation active participation students, sheets observation presentation and reports end and learn about the test results cognitive.The result showed that the active participation students increasing from 1 cycle ( $50 \%$ ) and cycle 2 ( $80 \%$ ).The increasing also seen in biology mean study results students is increasing from 1 cycle (69,60) and 2 cycle (72) .The study results work completed biology students is increasing from 1 cycle ( $70 \%$ ) and cycle 2 ( $100 \%)$. Based on the research done so conclude that the place where the application of a strategy group investigation be an increase in the of study result of the student of class XSMAMuhammadiyah Aimas tuning out of school in biology.

Key words: group investigation, the results of studied the biological, SMAMuhammadiyah Aimas

\section{PENDAHULUAN}

Pendidikan yang diselenggarakan di sekolah memiliki tujuan untuk merubah siswa agar dapat memiliki pengetahuan, keterampilan, dan sikap belajar sebagai bentuk perubahan tingkah laku hasil belajar. Penilaian pembelajaran tidak hanya terlihat dari hasil belajar di akhir pembelajaran, tetapi penilaian tersebut juga dilakukan selama kegiatan pembelajaran berlangsung. Tentu diperlukan suatu bentuk pembelajaran yang inovatif dan juga asessmen autentik untuk memenuhi tuntutan pembelajaran tersebut.

Nyatanya pembelajaran yang diterapkan lebih ditekankan kepada hasil tanpa memperdulikan pada proses. Pembelajaran hanya ditekankan pada nilai akhir siswa tanpa memperdulikan keterampilan dan sikap apa yang diperolehnya. Kurang diterapkannya pembelajaran yang mengasah keterampilan kerja dan sikap ilmiah siswa juga mengakibatkan kurang terbiasa memperoleh ilmu dengan langkah-langkah yang ada pada keterampilan proses sains.

Biologi merupakan salah satu ilmu sains yang memegang peran penting dalam pembentukan keterampilan dan daya berpikir nalar siswa. Pembelajaran Biologi SMA, diberikan sejak kelas X.
Salah satu materi yang diberikan adalah Ekosistem. Materi ini memiliki cakupan yang sangat luas sehingga siswa mengalami kesulitan dalam proses pembelajaran di kelas. Materi yang begitu banyak akan menyulitkan siswa untuk memahami materitersebut.

Guru memiliki peran yang besar dalam hal membelajarkan siswa, jadi guru seharusnya lebih mengutamakan apa yang telah diperoleh siswa dengan membuat siswanya lebih aktif dan ilmu yang diperolehnya lebih mengena. Guru mengubah kegiatan pembelajaran dari yang berorientasi pada guru (teacher centered) menjadi pembelajaran yang berorientasi pada siswa (student centered), menerapkan metode pembelajaran yang lebih menekankan pada kemampuan dan keterampilan proses sains dalam menemukan, dan memahami konsep dari materi pelajaran yang sedang dipelajari dengan melibatkan siswa dalam kegiatan belajar mengajar.

Kenyataannya guru pada saat mengajar di kelas lebih dominan menjelaskan materi dan belum menekankan pada keterampilan proses sains siswa. Para guru lebih banyak menilai ranah kognitif saja (Sudjana, 2009). Artinya, guru lebih menekankan 
pada aspek produk seperti hukum, prinsip, teori, dan konsep pelajaran.

Biologi merupakan salah satu ilmu yang penuh dengan materi hafalan dan bahasa latin. Siswa cenderung malas dan ngantuk ketika mengikuti pembelajaran biologi karena materi-materi yang padat dan tanpa adanya variasi metode pembelajaran. Siswa memiliki minat yang cukup rendah dalam mempelajari biologi. Hal ini dapat diketahui dari kurangnya aktivitas siswa saat proses belajar mengajar berlangsung. Siswa lebih cenderung beraktivitas lain yang tidak mendukung proses belajar mengajar.

Kurangnya minat belajar Biologi juga ditunjukan dengan nilai hasil ulangan yang tidak mencapaiKKM. Hal ini terbukti dari hasil belajar siswa, Kriteria ketuntasan minimal (KKM) pada materi Ekosistem adalah 65, sedangkan siswa yang mendapat nilai $\leq 65$ ada $45 \%$ dan $\geq 65$ ada $55 \%$. Hal ini menunjukan ketidakberhasilan proses pembelajaran ini dalam mencapai tujuan yang diharapkan. Ada beberapa faktor yang mempengaruhi rendahnya minat siswa terhadap pelajaran Biologi. Faktor-faktor tersebut meliputi suasana kelas yang kurang mendukung, kurangnya keaktifan siswa dalam proses pembelajaran yang terlihat dari kurangnya siswa bertanya dan menjawab, serta metode pembelajaran yang tidak bervariasi. Metode yang digunakan guru adalah ceramah, diskusi dan penugasan. Menurut Sardiman (2014), "dalam belajar sangat diperlukan adanya aktivitas belajar. Tanpa adanya aktivitas, belajar itu tidak mungkin akan berlangsung dengan baik".

Berdasarkan uraian tersebut, diperlukan strategi yang diharapkan berpengaruh terhadap hasil belajar siswa. Terkadang siswa juga merasa bosan dan tidak tertarik dengan apa yang dipelajari saat pembelajaran berlangsung karena siswa belum pernah diajak untuk menemukan dan memecahkan masalahnya sendiri. Perubahan-perubahan pada pola kegiatan belajar mengajar, penggunaan media pembelajaran yang tepat, dan memerlukan pola penilaian yang tepat merupakan alternatif untuk mengatasi masalahmasalah tersebut.

Menyikapi masalah tersebut strategi Group Investigation diharapkan mampu meningkatkan hasil belajar, karena pembelajaran GroupInvestigation adalah suatu proses pembelajaran yang melibatkan siswa secara aktif dalam proses mencari pengetahuan dengan sumber pengetahuan yang berasal dari pengalaman nyata sehari-hari.

Berdasarkan uraian di atas maka penulis tertarik untuk melakukan penelitian dengan mengambil judul "Penerapan Strategi Group Investigation untuk Meningkatkan Hasil Belajar Biologi Materi Ekosistem Bagi Siswa Kelas X SMA Muhammadiyah Aimas".

\section{METODE PENELITIAN}

Desain penelitian yang digunakan dalam penelitian ini adalah Penelitian Tindakan Kelas (PTK), karena bertujuan untuk memperbaiki dan meningkatkan kualitas pembelajaran serta membantu memberdayakan guru dalam memecahkan masalah pembelajaran di sekolah (Muslich, 2010).Desain penelitian tindakan kelas pada penelitian ini mengacu rancangan model Kemmis \& Taggart (2010), dimana masing-masing siklus pada penelitian ini terdiri dari empat tahapan yaitu, (1) perencanaan, (2) tindakan, (3) pengamatan, dan refleksi.

Penelitian dilaksanakan di SMA Muhammadiyah Aimas yang beralamat di Jalan KH. Ahmad Dahlan No 1 Mariyai Distrik Mariat Kabupaten Sorong. Pemilihan SMA Muhammadiyah Aimas, karena belum dimanfaatkannya Grup Investigation untuk pembelajaran Biologi. Penelitian ini dilaksanakan pada semester Genap Tahun Pelajaran 2016/2017mulai tanggal 1 Maret sampai dengan 1 Juni 2017.Subyek dalam penelitian ini adalah siswa kelas X SMA Muhammadiyah Aimas. Jumlah siswa kelas X adalah 20 orang, jumlah laki-laki 11 orang, dan perempuan 9 orang.Teknik pengumpulan data dan instrumen menggunakan observasi partisipan (lembar observasi partisipan), tes (ter tertulis), dan teknik dokumentasi.

Pelaksanaan penelitian tindakan kelas dilaksanakan dalam 2 siklus. Masing-masing siklus terdiri atas beberapa komponen yaitu perencanaan, pelaksanaan, pengamatan atau observasi dan refleksi. Proses perencanaan yang dilakukan oleh peneliti antara lain: a) Menyusun Rencana Pelaksanaan Pembelajaran (RPP) yang akan digunakan sebagai pedoman dalam pelaksanaan pembelajaran; b) Menyusun Lembar KerjaSiswa, Lembar Kerja Siswa (LKS); dan c) Menyusun LembarObservasi. Proses pelaksanaan tindakan dilakukan dengan melaksanakan perencanaan yang telah dibuat sebelumnya yaitu melaksanakan pembelajaran dengan menggunakan penerapan Strategi Group Investigation.Pelaksanaan tindakan dilaksanakan dalam dua siklus. Proses Pengamatan dilakukan mengetahui dampak tindakan terhadap proses pembelajaran dan penerapan group investigation tentang aktivitas siswa selama proses pembelajaran. Proses Refleksi dimana Peneliti mendiskusikan dengan guru mengenai hasil pengamatan yang dilakukan, kekurangan maupun ketercapaian pembelajaran untuk menyimpulkan data dan informasi yang berhasil dikumpulkan sebagai pertimbangan perencanaan pembelajaran siklus selanjutnya.

Hasil penelitian dianalisis menggunakan teknik analisa data deskriptif kuantitatif, yaitu bertujuan untuk mendeskripsikan data yang terkumpul dengan penyajian data melalui tabel, grafik, diagram lingkaran, perhitungan modus, mean, median, perhitungan persentase dan lain-lain (Sugiyono, 2013). Teknik ini digunakan untuk mendeskripsikan aktivitas dan hasil belajar siswa pada pembelajaran biologi dengan menerapkan group investigation di kelas X. 


\section{PEMBAHASAN}

\section{Kondisi Awal dan Perencanaan}

Berdasarkan refleksi hasil belajar pada mata pelajaran Biologi materi ekosistem pada tahun sebelumnya (2015), di kelas $X$ di SMA Muhammadiyah Aimas dikatakan rendah karena 58\% siswa yang nilainya di bawah 65 yang merupakan Kriteria Ketuntasan Minimal (KKM) yang telah ditentukan sekolah dengan melihat hasil ulangan harian.

Dalam proses pembelajaran guru menggunakan metode ceramah, diskusi, dan penugasan. Saat guru berceramah siswa hanya mendengarkan sambil mencatat. Sesekali guru melemparkan pertanyaan dan siswa menanggapinya dan jawaban tanggapan siswa terkadang tidak sesuai dengan pertanyaan guru. Metode yang kurang bervariasi ini yang membuat siswa kurang aktif dan cenderung pasif.

Selain metode pembelajaran yang kurang bervariasi dan hasil belajar siswa yang tidak mencapai Kriteria Ketuntasan Minimal (KKM), siswa juga cenderung pasif. Aktivitas siswa di kelas baik bertanya maupun menjawab terkait materi yang diajarkan sangat kurang. Siswa cenderung ramai tapi ramai mengobrol hal-hal lain di luar materi yang diajarkan.

\section{Hasil Tindakan}

Siklus 1

Sebelum melakukan penelitian dan kegiatan pembelajaran, peneliti terlebih dahulu membuat berbagai persiapan yang berkaitan dengan instrumen pembelajaran dan instrumen pengumpulan data. Instrumen pembelajaran yang disiapkan antara lain silabus dan Rencana Pelaksanaan Pembelajaran (RPP). Rencana Pelaksanaan Pembelajaran (RPP) merupakan rencana pelaksanaan pembelajaran yang berisi gambaran program pembelajaran yang akan diterapkan di dalam kelas. Semua kegiatan yang dilakukan pada proses pembelajaran akan disesuaikan dengan Rencana Pelaksanaan Pembelajaran (RPP) yang telah di buat. Selain itu pada tahap perencanaan ini juga peneliti menyiapkan semua instrumen pengumpulan data baik berupa lembar kerja siswa, handout, soal posttest yang akan membantu peneliti dalam mengumpulkandata.

Siklus I dilaksanakan dalam 2 kali pertemuan atau dalam 3 jam pelajaran. Kedua pertemuan tersebut meliputi beberapa kegiatan antara lain pembagian kelompok investigasi, perancangan kegiatan investigasi, pembuatan laporan akhir, presentasi hasil investigasi dan post-test siklus 1 .

Pertemuan pertama, hari Kamis 1 April 2017 dengan 2 jam pelajaran yaitu 90 menit. Kegiatan pertama yang dilakukan adalah memberikan apersepsi dan pertanyaan-pertanyaan kepada siswa dan siswa memberikan jawaban. Setelah menulis topik besar di papan tulis, guru memberikan beberapa pertanyaan yang berkaitan dengan topik sehingga siswa menanggapi hal-hal penting berkaitan dengan topik. Dari jawaban-jawaban siswa tersebut, siswa diarahkan untuk membentuk kelompok yang terdiri dari 5 orang dan kelompok dibentuk berdasarkan pilihan daerah Ekosistem yang ingin diinvestigasi oleh siswa. Pilihan Investigasi siswa tersebut antara lain Ekosistem Sungai, Ekosistem Ladang, Ekosistem Hutan, dan Ekosistem Sekolah. Untuk siklus 1 yang diinvestigasi adalah berkaitan dengan komponen penyusun ekosistem dan interaksi yang terjadi di dalam ekosistem tersebut. Setelah kelompok terbentuk, siswa dibagikan Lembar Kerja Siswa (LKS) dan siswa melaksanakan perencanaan investigasi. Selama kegiatan diskusi perencanaan, peneliti berkeliling untuk melihat kesiapan siswa dan menjawab semua pertanyaan-pertanyaan siswa dan menuntun siswa dan mengarahkan kelompok yang belum benar dalam perencanaannya. Waktu diskusi 30 menit. Selesai membuat perencanaan, menugaskan siswa untuk melakukan kegiatan penyelidikan. Penyelidikan dilakukan melalui tinjauan pustaka. Siswa juga ditugasi untuk membuat laporan akhir hasil penyelidikan dan menyiapkan presentasi.

Sebelum presentasi peneliti memeriksa kesiapan siswa dan memberikan motivasi kepada siswa dan selanjutnya peneliti meminta semua kelompok mengumpulkan terlebih dahulu laporan hasil penyelidikan. Kelompok yang presentasi pada hari itu ada 3 kelompok dan setiap kelompok mendapat kesempatan 10 menit presentasi dan tanya jawab. Selesai jam pelajaran guru menutup pembelajaran tanpa adanya penjelasan karena masih ada 1 kelompok yang belum presentasi.

Pertemuan kedua, 4 April 2017 dengan 1 jam pelajaran yaitu 45 menit diisi dengan presentasi 1 kelompok, penguatan dan klarifikasi dari peneliti dan dilanjutkan dengan post- test. Setelah semua siap, peneliti membagikan lembar soal post-test siklus 1 kepada siswa dan siswa diminta untuk mengerjakan langsung dilembar yang dibagikan. Post-test siklus 1 dilakukan selama 25 menit.

\section{3) Hasil Observasi}

Selama kegiatan belajar mengajar berlangsung observer melakukan pengamatan secara langsung mengenai partisipasi yang ditunjukkan oleh siswa dalam mata pelajaran Biologi. Dalam penelitian ini, unsur-unsur yang termasuk dalam partisipasi siswa atau keaktifan siswa meliputi aspek bertanya dan menjawab pertanyaan. Tingkat keaktifan siswa pada siklus 1 sebagai berikut:

Tabel 1. Hasil Observasi Partisipasi Aktif Siswa pada Siklus 1

\begin{tabular}{|c|c|c|}
\hline \multirow[b]{2}{*}{ Skala } & \multicolumn{2}{|c|}{ Partisipasi Aktif } \\
\hline & $\begin{array}{l}\text { Jumlah } \\
\text { siswa }\end{array}$ & Persentase \\
\hline Tidak Aktif & 2 & $10.00 \%$ \\
\hline Kurang Aktif & 6 & $30.00 \%$ \\
\hline Cukup Aktif & 2 & $10.00 \%$ \\
\hline Aktif & 4 & $20.00 \%$ \\
\hline Sangat Aktif & 6 & $30.00 \%$ \\
\hline
\end{tabular}


Dari tabel di atas dapat diketahui bahwa aktivitas siswa sebagian besar masih dalam kategori kurang aktif, dimana terdapat 10 siswa dengan kategori tidak aktif hingga cukup aktif dengan persentase $50 \%$. Sementara dalam kategori aktif dan sangat aktif terdapat 10 sswa dengan persentase $50 \%$.

Pada hasil analisis tes ini didapat data yang berupa angka-angka mengenai jumlah nilai yang diperoleh masing-masing siswa terhadap soal yang dikerjakan setelah menerapkan Group Investigation dalam proses mata pelajaran Biologi. Adapun hasil perhitungannya sebagai berikut:

Tabel 2. Hasil Perhitungan Tes pada Siklus 1

\begin{tabular}{lc}
\hline Nilai akhir & Pencapaian \\
\hline Nilai tertinggi & 80 \\
Nilai terendah & 60 \\
$\begin{array}{l}\text { Rata-rata } \\
\text { Jumlah siswa yang tuntas } \\
\text { belajar } \geq 65\end{array}$ & 69.60 \\
$\begin{array}{l}\text { Jumlah siswa yang tidak } \\
\text { tuntas belajar < 65 }\end{array}$ & 14 \\
$\begin{array}{l}\text { Persentase ketuntasan } \\
\text { belajar secara klasikal }\end{array}$ & 6 \\
\hline
\end{tabular}

Berdasarkan tabel di atas, peneliti mendapatkan bahwa rata-rata nilai akhir siswa adalah 69.60. Secara klasikal, siswa yang memperoleh nilai total $\geq 65$ ada 14 orang siswa dengan persentase ketuntasan belajar $70 \%$, sedangkan 6 orang siswa mendapat total nilai $\leq 65$ dengan persentase ketidaktuntasan belajar sebesar $30 \%$.

Dalam pembelajaran pada siklus 1 ini, berdasarkan data yang dijabarkan di atas dapat dilihat baik aktivitas siswa maupun nilai akhir siswa belum mencapai target yang diharapkan yaitu untuk aktivitas $75 \%$ dan untuk nilai akhir siswa juga $80 \%$.

Kegiatan pembelajaran untuk siklus 1 ini belum berjalan secara baik karena beberapa hal antara lain kurangnya keinginan siswa untuk membaca buku saat melakukan investigasi sehingga apa yang mereka investigasi hanyalah sesuai dengan apa yang dipikiran mereka.

Selain itu tingkat keaktifan siswa masih terbilang rendah, hanya ada orang-orang tertentu yang aktif sedangkan yang lain mengikuti saja. Hal ini bisa dikarenakan metode ini masih tergolong baru bagi siswa dan siswa butuh penyesuaian untuk bisa mengikuti proses pembelajaran dengan baik.

Berdasarkan hasil refleksi tersebut, maka perlu adanya tindakan lanjutan untuk memperbaiki atau menyempurnakan pembelajaran, dengan melanjutkan ke siklus 2 .

Siklus 2

Perencanaan pada siklus 2 ini dilakukan berdasarkan refleksi yang ada pada siklus 1 . Perencanaan ini diharapkan bisa memperbaiki kekurangan pada siklus 1. Beberapa hal yang perlu diperbaiki oleh peneliti antara lain peneliti harus lebih semangat dalam memberikan motivasi kepada siswa untuk mau membaca buku dan mencari sumber lainnya yang dapat membantu mereka dalam investigasi kelompok. Peneliti juga harus lebih memperhatikan siswa saat diskusi sehingga peneliti dapat membantu jika siswa masih ada kesulitan.

Pelaksanaan siklus 2 dilaksanakan dalam 2 kali pertemuan dengan kegiatan penyampaian topik, pembentukan kelompok, perancangan pelaksanaan, investigasi kelompok, pembuatan laporan akhir, presentasi kelompok dan posttest siklus 2. Proses pembelajaran berlangsung sesuai dengan Rencana Pelaksanaan Pembelajaran yang telah dibuat sebelum pelaksanaan penelitian.

Pertemuan pertama siklus 2, pada hari Sabtu, 8 April 2017 selama 2 jam pelajaran. Sebelum memulai pembelajaran, peneliti memeriksa kesiapan siswa dalam mengikuti pelajaran. Selanjutnya peneliti memberikan apersepsi dan motivasi kepada siswa. Selanjutnya, peneliti menyampaikan topik pembelajaran. Untuk siklus 2 yang dipelajari adalah Aliran Energi dalam Ekosistem. Tempat atau Ekosistem yang akan diinvestigasi masih sama yaitu Ekosistem sungai, Ekosistem Ladang, Ekosistem Hutan, dan Ekosistem sekolah. Setelah penyampaian topik, guru membimbing siswa untuk membentuk kelompok baru berdasarkan tempat yang ingin diinvestigasi oleh siswa. Satu kelompok terdiri dari 5 siswa. setelah terbentuk kelompok siswa dibimbing untuk duduk dalam kelompok dan berdiskusi untuk merencanakan investigasi yang akan dilakukan. Peneliti membagikan Lembar Kerja Siswa (LKS) yang berisi pertanyaan penuntun yang membantu siswa untuk merancang investigasi. Peneliti juga membagikan handout tentang materi pembelajaran siklus 2 kepada siswa. Selanjutnya kegiatan yang dilakukan adalah presentasi kelompok dan penegasan serta klarifikasi dari peneliti tentang apa yang dipresentasikan. Sebelum presentasi semua siswa diminta untukmengumpulkan terlebih dahulu laporan Hasil Investigasi. Presentasi dilakukan selama 30 menit dan setiap kelompok mendapat waktu 10 menit presentasi dan Tanya-jawab. Pertanyaan untuk satu kelompok dibatasi hanya 2 pertanyaan. Setelah semua kelompok selesai mempresentasikan hasil investigasi kelompok mereka peneliti mengklarifikasi dan memberikan penguatan tentang materi yang dipresentasikan oleh kelompok tadi. Sebelum menutup pelajaran, peneliti mengajak siswa untuk bertepuk tangan karena hasil investigasi dan presentasi yang mereka lakukan sudah cukup bagus. Peneliti selanjutnya memberikan tugas kepada siswa untuk mempelajari materi karena akan ada posttest pada pertemuanselanjutnya.

Pertemuan kedua pada hari Selasa, 11 April 2017 selama 1 jam pelajaran. Pada pertemuan ini kegiatan yang dilaksanakan adalah melanjutkan presentasi kelompok 4 yang belum selesai pada pertemuan yang lalu dan dilanjutkan dengan posttest siklus 2 . Sebelum membagikan soal posttest, peneliti meminta siswa untuk menutup semua buku Biologi dan menyimpannya di dalam tas. Setelah semua siap, 
peneliti baru membagikan lembar soal posttest 2 kepada siswa.

Selama kegiatan belajar mengajar berlangsung observer melakukan pengamatan secara langsung mengenai partisipasi yang ditunjukkan oleh siswa dalam mata pelajaran Biologi. Dalam penelitian ini, unsur-unsur yang termasuk dalam partisipasi siswa atau keaktifan siswa meliputi aspek bertanya dan menjawab pertanyaan. Tingkat keaktifan siswa pada siklus 2 sebagai berikut:

Tabel 3. Hasil Observasi Partisipasi Aktif Siswa pada Siklus 2

\begin{tabular}{|c|c|c|}
\hline \multirow[b]{2}{*}{ Skala } & \multicolumn{2}{|c|}{ Partisipasi Aktif } \\
\hline & $\begin{array}{l}\text { Jumlah } \\
\text { siswa }\end{array}$ & Persentase \\
\hline Tidak Aktif & 0 & $0.00 \%$ \\
\hline Kurang Aktif & 0 & $0.00 \%$ \\
\hline Cukup Aktif & 4 & $20.00 \%$ \\
\hline Aktif & 9 & $45.00 \%$ \\
\hline Sangat Aktif & 7 & $35.00 \%$ \\
\hline
\end{tabular}

Dari tabel di atas dapat diketahui bahwa aktivitas siswa menjadi sangat baik, dimana terdapat 16 siswa dalam kategori aktif dan sangat aktif dengan persentase $80 \%$.

Pada hasil analisis tes ini didapat data yang berupa angka-angka mengenai jumlah nilai yang diperoleh masing-masing siswa terhadap soal yang dikerjakan setelah menerapkan Group Investigation dalam proses mata pelajaran Biologi. Adapun hasil perhitungannya sebagai berikut:

Tabel 4. Hasil Perhitungan Tes pada Siklus 2

\begin{tabular}{lll}
\hline & $\mathrm{N}$ & Pencapaian \\
\hline Nilai tertinggi & & 82 \\
Nilai terendah & & 66 \\
Rata-rata & & 72.00 \\
Jumlah siswa yang tuntas & 20 \\
Jumlah siswa yang tidak & 0 \\
Persentase & ketuntasan & $100 \%$ \\
\hline
\end{tabular}

Berdasarkan tabel di atas, peneliti mendapatkan bahwa rata-rata nilai akhir siswa adalah 72 . Secara klasikal, siswa yang memperoleh nilai total $\geq 65$ ada 20 orang siswa dengan persentase ketuntasan belajar $100 \%$.

Berdasarkan data yang dijabarkan diatas dapat dilihat bahwa untuk siklus 2 hasilnya sangat memuaskan baik aktivitas siswa maupun nilai akhir siswa karena hasilnya mencapai target yang diharapkan yaitu untuk aktivitas $75 \%$ dan untuk nilai akhir siswa juga $80 \%$. Untuk tingkat keaktivan siswa mencapai $80 \%$ siswa yang tergolong sangat aktif dan aktif. Sedangkan untuk nilai hasil akhir siswa mencapai $100 \%$ siswa yang mencapai Kriteria Ketuntasan Minimal (KKM). Kriteria Ketuntasan Minimal (KKM) yang ditentukan dari sekolah adalah 65. Hasil ini sangat memuaskan karena baik keaktifan maupun nilai akhir siswa melebihi target yang diharapkan.
Dari hasil analisis peneliti menunjukkan pada siklus 2, siswa kelas $\mathrm{X}$ mengalami peningkatan dalam hal hasil belajar dan aktivitas siswa di kelas dibandingkan dengan siklus sebelumnya. Hasil ini telah mencapai target ataupun standar penelitian tindakan kelas yang ditargetkan dalam penelitian. Karena hasilnya telah mencapai target yang diharapkan maka tidak perlu diadakan penambahan siklus pada kegiatan selanjutnya.

Penilaian yang digunakan pada setiap siklus adalah dengan menggunakan tes dan dilaksanakan pada setiap akhir siklus dengan soal-soal yang sesuai dengan materi yang diberikan kepada siswa. Hasil penelitian tindakan siklus 1 dan 2 dengan penggunaan Group Investigation menunjukkan adanya peningkatan terhadap hasil belajar siswa.Peningkatan hasil belajar siswa dapat dilihat pada diagram sebagai berikut:

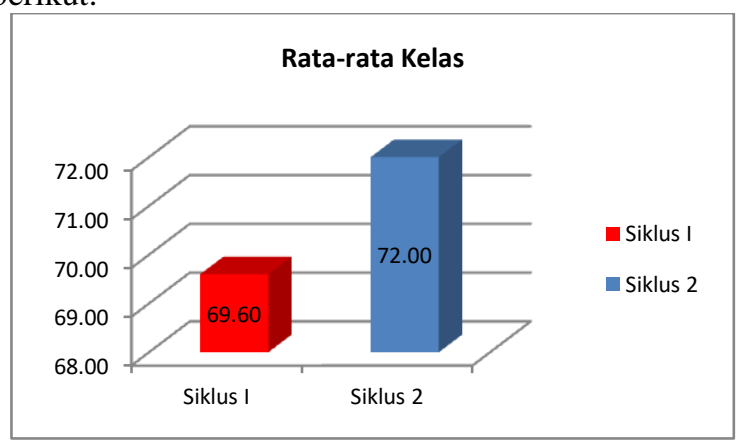

Gambar 1. Diagram Nilai Rata-Rata Kelas

Pada diagram di atas menunjukkan bahwa terdapat peningkatan rata-rata nilai hasil belajar dari siklus sebesar 69,60, sedangkan pada siklus 2 meningkat menjadi sebesar 72 .

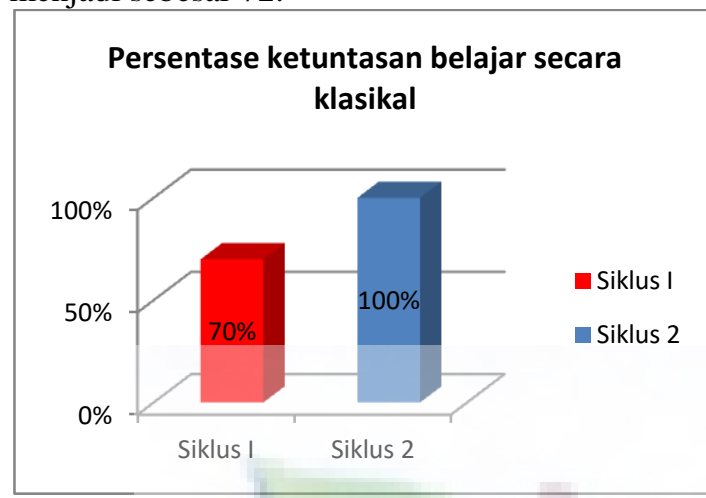

Gambar 2. Diagram Persentase Ketuntasan Klasikal

Pada diagram di atas menunjukkan bahwa terdapat peningkatan persentase ketuntasan klasikal. Siklus 1 terdapat $70 \%$ siswa yang telah mencapai ketuntasan atau mencapai Kriteria Ketuntasan Minimal (KKM). Sedangkan pada siklus 2 terdapat $100 \%$ siswa telah mencapai KKM.

Hasil penelitian tindakan siklus 1 dan 2 dengan penggunaan Group Investigation (GI) menunjukkan adanya peningkatan terhadap aktivitas belajar siswa. Peningkatan terjadi pada observasi siklus 2 di mana dalam observasi ini yang diamati adalah partisipasi aktif siswa. Dari hasil observasi diperoleh data aktivitas siswa sebagai berikut: 


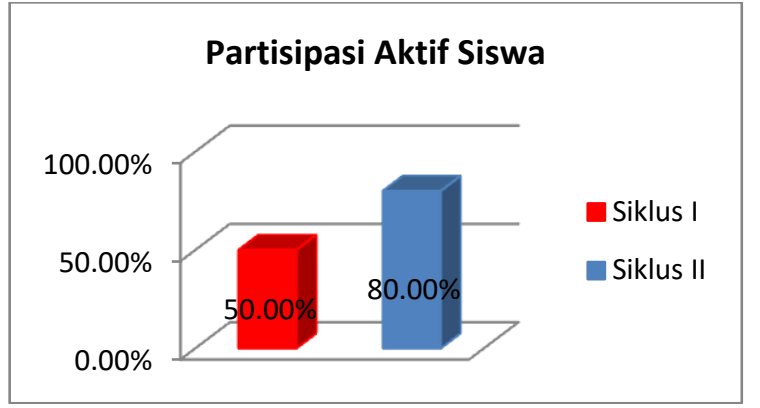

Gambar 3. Peningkatan Partisipasi Aktif Siklus 1 dan Siklus 2

Berdasarkan hasil observasi yang dapat dilihat dari tabel di atas dapat dilihat adanya peningkatan partisipasi aktif dari siklus 1 sampai ke siklus 2. Pada siklus 1 terdapat 10 siswa yang masuk kriteria aktif dan sangat aktif dengan presentasi keaktifan 50\%, sedangkan pada siklus 2 terdapat 20 siswa yang masuk kriteria aktif dan sangat aktif dengan presentase $100 \%$. Dari analisis data keaktifan siswa pada siklus 1 dan siklus 2 terjadi peningkatan dan peningkatan ini mencapai target penelitian tindakan kelas yang telah ditargetkan oleh peneliti yaitu $80 \%$ siswa masuk kategori aktif.Perubahan partisipasi aktif siswa juga tergantung pada guru, apabila guru kurang berinteraksi dengan siswa maka proses belajar mengajar akan terasa kurang lancar yang menyebabkan siswa enggan berpartisipasi secara aktif dalam proses pembelajaran (Roestiyah, 2008).

Berdasarkan analisis yang dilakukan pada keaktifan dan hasil belajar siswa di atas dapat kita lihat bahwa suatu proses pembelajaran yang melibatkan guru dan siswa akan menghasilkan suatu perubahan dalam diri siswa sebagai hasil dari kegiatan pembelajaran. Adanya perubahan keaktifan dan hasil belajar siswa ini karena dalam pembelajaran ini siswa dituntut untuk aktif bekerja dan pada akhirnya proses ini menghasilkan suatu kondisi belajar aktif.

Dari hasil penelitian yang dilakukan, peneliti dapat mengetahui bahwa strategi Group Investigation cocok digunakan pada pokok bahasan Ekosistem. Hal ini dapat dilihat dari hasil yang diperoleh siswa kelas $\mathrm{X}$ pada tiap siklus kegiatan pembelajaran yang mengalami peningkatan baik pada keaktifan siswa maupun hasil belajar siswa di dalam kelas. Hal ini sejalan dengan penelitian yang dilakukan Dewi (2012) yang mengungkapkan bahwa penerapan model pembelajaran kooperatif Group Investigation dapat meningkatkan hasil belajar biologi siswa pada ranah pengetahuan. Demikian pula hasil temuan Susi $d k k$ (2016), bahwa pembelajaran group investigation dapat meningkatkan hasil belajar siswa apalagi kepada siswa yang memiliki tingkat motivasi yang tinggi.

\section{KESIMPULAN}

Berdasarkan hasil penelitian dan pembahasan, dapat ditarik kesimpulan sebagai berikut: a) Penerapan pembelajaran dengan menggunakan Group Investigation dapat meningkatkan partisipasi aktif siswa Kelas $\mathrm{X}$ dilihat dari adanya peningkatan persentase pada siklus 1 sebesar $50 \%$ dan siklus 2 sebesar $80 \%$ dan b) Group Investigation juga dapat meningkatkan hasil belajar di kelas. Peningkatan hasil belajar ini dapat dilihat dari adanya perubahan nilai rata-rata yang diperoleh siswa pada setiap akhir siklus. Nilai rata-rata yang diperoleh siswa pada siklus 1 sebesar 69,60 dan siklus 2 sebesar 70. Hal tersebut membuktikan bahwa dengan menggunakan Group Investigation dapat meningkatkan hasil belajar siswa.

\section{DAFTAR PUSTAKA}

Dewi, Ratih Puspita. (2012). Penerapan Model Group Investigation Terhadap Hasil Belajar Materi Bahan Kimia Di SMP. Jurnal MIPA. HIm. 1-8

Kemmis \& Mc. Taggart. (2010). The Action Research Planner. Geelong: Deaken Univercity Press.

Muslich, M. (2010. Pembelajaran Berbasis Kompetensi dan Kontekstual. Jakarta: Bumi Aksara.

Roestiyah. (2008). Strategi belajar Mengajar. Jakarta: Rineka Cipta

Sardiman, A.M. (2014). Interaksi \& Motivasi Belajar Mengajar. Jakarta: Rajawali Press.

Sudjana, Nana. (2009). Penilaian Hasil Proses Belajar Mengajar. Bandung: PT Remaja Rosdakarya.

Sugiyono. (2013). Metode Penelitian Kuantitatif, Kualitatif, dan $R \& D$. Bandung: Alfabeta.

Susi, Pransiska., Rayandra Asyhar dan Asrial (2016). "Pengaruh Penerapan Model pembelajaranGroup Investigation dan Motivasi Terhadap Hasil Belajar Siswa kelas VII SMP Dalam Pembelajaran IPA Terpadu Pada Materi Asam, Basa, Dan Garam”. Edu-Sains Vol. 5, No 2 